\title{
Enteral Versus Parenteral Feeding: The Avoidance of Systemic Infection in the Critically III
}

\author{
Christine M. Finck Giovanni F. Torelli Michael M. Meguid \\ Madhu Varma Rebecca Evangelista
}

Surgical Metabolism and Nutrition Laboratory, Department of Surgery, University Hospital, SUNY Health Science Center, Syracuse, N.Y., USA

\section{Key Words}

Enteral nutrition - Parenteral nutrition .

Sepsis · Infectious diseases

\begin{abstract}
The critically ill patient very often presents with systemic evidence of infection including tachypnea, tachycardia and hypo-hyperthermia; this may lead to sepsis syndrome and subsequent multisystem organ failure. In order to manage this clinical condition, nutritional supportive therapy is very often required. The choice between enteral and parenteral nutrition is not always straightforward. Early enteral nutrition seems to exert beneficial effects, although parenteral nutrition is often easier to administer, and thus is the treatment of choice. There are only few prospective, randomized, controlled trials
\end{abstract}

comparing the two methods of intervention therapy. Parenteral nutrition seems to be associated with mechanical, metabolic and septic complications, while enteral nutrition, which is associated with similar complications, prevents gastrointestinal mucosal atrophy, attenuates the injury stress response, maintains immunocompetence, and preserves normal gut flora. This literature review focuses on the role played by these two methods of nutritional support therapy in the development of systemic infections. This review will also analyze possible mechanisms of action and future therapeutic strategies.

\begin{tabular}{ll}
\hline KARGER & @ 1999 S. Karger AG, Basel \\
Fax +4161306 12 34 & 1011-7571/99/0082-0077\$17.50/0 \\
$\begin{array}{l}\text { E-Mail karger@karger.ch } \\
\text { www.karger.com }\end{array}$ & Accessible online at: \\
http://BioMedNet.com/karger
\end{tabular}

Dr. Michael M. Meguid, MD, PhD, FACS, Department of Surgery University Hospital, SUNY Health Science Center 750 East Adams Street, Syracuse, NY 13210 (USA) Tel. +1 3154646277 , Fax +1 3154646237 E-Mailmeguidm@mailbox.hscsyr.edu 


\section{Introduction}

Supportive nutritional therapy is one of the most important elements of caring for the critically ill and high-risk surgical patient [1]. Hypermetabolic states lead to a pathophysiological progressive depletion of usual energy reserves as well as to loss of body muscle mass, and results in several related complications. These include increased risk of infection, impaired wound healing, organ dysfunction and possible multiple system organ failure [2]. The goals of supportive nutritional therapy in a critically ill patient include detecting and correcting any preexisting malnutrition, preventing the progressive onset of protein calorie malnutrition, optimizing the patient's metabolic state, with the intent of decreasing the morbidity, mortality, and duration of recovery.

The decision as to whether to provide either enteral or parenteral supportive nutritional therapy is not always straightforward. Parenteral feeding is often easier to initiate and administer, but in the last few years accumulated evidence shows that enteral feeding (ENT) has many advantages over total parenteral nutrition (TPN) [3-6]. TPN is generally associated with higher costs, and with complications now recognized to include impaired gastrointestinal barrier. Traditionally, complications associated with the use of TPN have also included profound metabolic disturbances such as hyperglycemia and hypertriglyceridemia, immunosuppression by intravenous fat, and mechanical complications associated with central venous cannulation such as pneumothorax, venous thrombosis and catheter-related sepsis [7-9]. However, the latter are now recognized as not being related to TPN per se, but to the injudicious and careless use of this form of intravenous therapy. Of the former complications, systemic sepsis is one of the more interesting because it is thought to be related to TPN-associated disuse gut atrophy [10-13].

\section{Enteral versus Parenteral Feeding in Clinical Trials: A Difference in Septic Morbidity}

A number of clinical trials have demonstrated a reduced risk of septic complications with enteral nutrition (table 1), even if it is not clear whether the observed benefits were associated with the use of ENT or the avoidance of the detrimental effects of TPN. Among these studies, there is a subset that investigated the effect of different feeding routes on normally nourished patients with major abdominal trauma.

Moore and Jones [10] randomized 75 patients with an abdominal trauma index (ATI) $>15$ to receive either intravenous $\mathrm{D}_{5} \mathrm{~W}$ (control group) or enteral nutrition via needlecatheter jejunostomy postoperatively. Although the overall complication rates were similar, significantly more septic complications occurred in the control group. Among patients with an ATI between 15 and 40, 26\% of control versus only $4 \%$ of the ENT group developed postoperative infections.

A follow-up study comparing ENT-fed with TPN-fed patients showed similar results [11]. The incidence of major septic morbidity (defined as pneumonia or intra-abdominal abscess) was 3\% for the ENT group as compared to 20\% for the TPN group. Furthermore, the overall septic incidence in the TPN group was twice that of the ENT group.

A similar study compared the effect of feeding route on septic morbidity following blunt or penetrating abdominal trauma [12]. Ninety-eight patients requiring emergency laparotomy with an ATI of 15 or greater were randomized to receive TPN or ENT within 
Table 1. Randomized prospective studies of enteral and parenteral feeding in patients with trauma or high surgical risk

\begin{tabular}{|c|c|}
\hline Study & Results \\
\hline $\begin{array}{l}\text { Moore and Jones [10]: } 75 \text { abdominal trauma patients } \\
\text { randomized to receive enteral nutrition (via a jejunos- } \\
\text { tomy) or i.v. } D_{5} W \text { (control group) }\end{array}$ & $\begin{array}{l}\text { significantly more septic complications occurred in the } \\
\text { control group among patients with an ATI between } 15 \\
\text { and } 40,26 \% \text { of control versus only } 4 \% \text { of the ENT } \\
\text { group developed postoperative infections }\end{array}$ \\
\hline $\begin{array}{l}\text { Moore et al. [11]: follow-up study comparing ENT-fed } \\
\text { with TPN-fed patients following major abdominal } \\
\text { trauma }\end{array}$ & $\begin{array}{l}\text { the incidence of major septic morbidity was } 3 \% \text { for the } \\
\text { ENT group compared to } 20 \% \text { for the TPN group }\end{array}$ \\
\hline $\begin{array}{l}\text { Kudsk et al. [12]: } 98 \text { patients with an ATI of } 15 \text { or } \\
\text { greater requiring emergency laparotomy were random- } \\
\text { ized to receive TPN or ENT }\end{array}$ & $\begin{array}{l}\text { enterally fed patients developed significantly fewer } \\
\text { infections; patients with both an ATI > } 24 \text { and an ISS } \\
>20 \text { in the TPN-fed group had a } 11 \text {-fold increased risk } \\
\text { of infection over the same subset of ENT-fed patients }\end{array}$ \\
\hline $\begin{array}{l}\text { Moore et al. [13]: meta-analysis of eight prospective } \\
\text { randomized trials designed to compare ENT versus } \\
\text { TPN nutrition in high-risk surgical patients }\end{array}$ & $\begin{array}{l}\text { significantly more septic complications occurred in } \\
\text { parenterally fed patients; the most significant differ- } \\
\text { ences were observed among all trauma and blunt trau- } \\
\text { ma groups }\end{array}$ \\
\hline
\end{tabular}

$24 \mathrm{~h}$ of injury. Enterally fed patients developed significantly fewer infections including pneumonia, abscesses and catheter sepsis as well as fewer infections per patient. Significance was reached only in patients with an ATI greater than 24 or the injury severity score (ISS) greater than 20. Patients with both an ATI $>24$ and an ISS >20, and who had been randomized to the TPN-fed group, had an 11-fold increased risk of infection over the same subset of ENT-fed patients.

A meta-analysis of eight prospective randomized trials designed to compare the incidence of infections in patients receiving either ENT or TPN supportive therapy in high-risk surgical patients also demonstrated similar findings [13]. This two-part analysis confirmed that significantly more septic complications occurred in parenterally fed patients. The most significant differences were ob- served among all trauma and blunt trauma groups. Differences remained significant even after patients with catheter sepsis were excluded.

\section{Suggested Mechanism}

Bacterial translocation has recently gained increasing recognition as an important cause of septic complications. Several animal studies have suggested that enteral feeding reduces bacterial translocation, and thus by inference reduces the risk of septic morbidity. One such study compared intravenous to oral TPN in Fischer rats with a chow-fed group serving as controls [14]. A significantly greater number of culture-positive mesenteric lymph nodes were found in the parenterally fed animals. No positive nodes were found in the control 
group. Translocating organisms included Escherichia coli and Proteus mirabilis. Both the oral-TPN and intravenous-TPN groups had similar and significant increases in cecal bacterial counts compared to the control group. Measurement of secretory IgA concentration in bile, however, showed that the intravenousTPN group had a significant decrease in secretory IgA, whereas no difference was noted between the oral-TPN and control groups. The authors suggested that, despite a similar increase in cecal bacterial counts, translocation in the oral-TPN group may not have been as significant due to the maintenance of immunologic functions. In addition, they noted that the intravenous-TPN group remained healthy and gained weight throughout the study, suggesting that systemic spread of translocated bacteria may become an issue only during extreme stress and the immunosuppression which accompanies trauma, anesthesia and surgery.

As suggested by this and the other studies, the normal bowel prevents bacterial translocation by way of the barrier and the immune function. Deitch et al. [15] designed a study in which they directly assessed both these functions, utilizing in vivo and ex vivo studies of rat ileum. The magnitude of E. coli and phenol red transmucosal passage was significantly higher in the intravenous TPN group, indicating increased intestinal permeability and bacterial translocation. This led the authors to conclude that a loss of barrier function plays a key role in nutritionally induced bacterial translocation.

The role of mucosal atrophy as a possible cause of decreased barrier function has also received much attention [11]. The occurrence of intestinal villus atrophy after periods of parenteral feeding is well documented in rats [16] as well as normal human volunteers [17]. To investigate the role this may play in bacterial translocation, recent studies have focused on glutamine and its essential role in gut mucosal growth. The lack of glutamine, a semiessential amino acid, in TPN solutions has been a proposed cause of the atrophyinduced bacterial translocation. A study of 12 ICU patients, randomized to receive standard TPN or Ala-glutamine-enriched TPN, showed significantly improved intestinal absorption in the patients receiving the enriched solution [18]. Furthermore, a study done in rats comparing standard TPN to glutamineenriched TPN showed that the supplemented solution protected against bacterial translocation [19] and attenuated mucosal atrophy in TPN rats [20], although the mucosal thickness was still significantly less than that achieved with normal ENT nutrition. However, it is important to keep in mind that the relationship between atrophy and bacterial translocation remains unclear. In fact, one study on protein-malnourished mice found no correlation between the histologic appearance of the gut mucosa and the magnitude of bacterial translocation [21].

Intestinal immune response to different feeding routes has also been investigated. In a study of healthy volunteers, Fong et al. [22] investigated the hypothesis that bowel rest may enhance endotoxin translocation and thus alter the response to infection. Twelve volunteers were randomized to receive 7 days of either enteral feeding or TPN only. Serum glucagon and epinephrine, hepatic venous cachectin/tumor necrosis factor, extremity efflux of lactate and amino acids, and C-reactive protein were significantly higher in the TPN group. This suggests that TPN, in addition to increasing bacterial translocation, may enhance the response to infection by an exaggerated counterregulatory hormone response and increased production of cytokines, as initially reported from our laboratory [23]. Tumor necrosis factor, in particular, has been shown to induce the release of a number of
80

Med Principles Pract 1999;8:77-84
Finck/Torelli/Meguid/Varma/ Evangelista 
Table 2. Sepsis outcome in studies evaluating supplementation of enteral feeding

\begin{tabular}{ll}
\hline Study & Results \\
\hline $\begin{array}{l}\text { Cerra et al. [29], Bower et al. [30]: enteral diet contain- } \\
\text { ing increased amounts of } \omega-3 \text { fatty acids, arginine and }\end{array}$ & $\begin{array}{l}\text { infectious complications and hospital lengths-of-stay } \\
\text { were decreased in patients who received the modified } \\
\text { ribonucleic acids compared to a standard enteral for- } \\
\text { mula diet }\end{array}$ \\
\hline
\end{tabular}

Moore et al. [31], Kudsk et al. [32]: enteral formula diet containing additional glutamine, arginine, nucleic acids, and $\omega-3$ fatty acids compared to a standard amino acid-based elemental diet

Klimberg et al. [36], Muscaritoli et al. [37]: supplementation of glutamine in experimental models and in humans following radio- and/or chemotherapy

Spaeth et al. [38], Wells et al. [39]: supplementation of dietary fiber in experimental models

Veerabagu et al. [40]: administration of nucleosides/ nucleotide in an experimental model of indomethacininduced enterocolitis less multiorgan failure and fewer major infectious complications in patients who received the modified formula

ability of glutamine to protect gut brush border, limiting bacterial translocation, and to attenuate mucosal atrophy

improved intestinal barrier function and decreased incidence of bacterial translocation, even in the absence of oral nutrients

increase in cellular proliferation and decreased small bowel ulcer length secondary mediators such as interleukin-1, catecholamines, and cortisol, which produce, catabolic effects [24].

Moreover, during parenteral nutrition, the clearance activity of Kupffer cells is assumed to be increased. This might consequently result in a conversion of hepatic synthesis of visceral constitutive proteins (fibronectin, prealbumin, and transferrin) toward generation of acute phase proteins (C-reactive protein and $\alpha_{1}$-acid glycoprotein) $[25,26]$. On the other hand, the presence of enteral nutrients appears to promote mucosal health, which is reflected by better maintenance of intestinal absorption capacity [27] and conserved gastrointestinal barrier function. This may result in improving visceral protein synthesis [28] as well as carbohydrate homeostasis [27].

\section{Possible Future Therapeutic Strategies}

Several studies have evaluated the effects of various enteral formulas which were supplemented with selected nutrients on clinical outcome (table 2).

Two prospective randomized clinical trials $[29,30]$ compared an enteral diet containing increased amounts of $\omega-3$ fatty acids, arginine and ribonucleic acids to a standard enteral formula diet. The authors from both studies concluded that infectious complications and hospital length-of-stay were decreased in patients who received the modified formula, mainly because of the immunostimulatory properties of the supplemented formula, based on a marked stimulation of in vitro lymphocyte proliferation responses [30]. An- 
other study found that patients given a modified formula diet containing additional glutamine, arginine, nucleic acids, and $\omega-3$ fatty acids had less multiorgan failure than those given a standard amino acid-based elemental diet [31]. A recent trial comparing the modified diet with a protein-supplemented standard enteral formula found that patients who received the enriched formula had fewer major infectious complications [32].

As discussed above, researchers have focused their attention on glutamine [33-35], because of its ability in protecting gut brush border and thus limiting bacterial translocation, both in experimental models [36] and in humans [37] following a variety of stresses including bone marrow transplantation, the critically ill ICU patient, on radio- and/or chemotherapy. This is probably due to the role played by glutamine as an energy source for the enterocyte: catabolic stress markedly increases the needs for glutamine which becomes an essential substrate for damaged intestinal mucosa.

Instead of glutamine, some researchers suggest that dietary fiber alone may be one of the key elements that protects against mucosal changes and bacterial translocation [38, 39]. They found that oral administration of cellulose powder improves intestinal barrier function and decreases the incidence of bacterial translocation, even in the absence of oral nutrients.

More recently our laboratory showed that parenteral administration of nucleosides/nucleotide exerts beneficial effects on an experimental model of an indomethacin-induced enterocolitis [40]. The protective effect occurred mainly via an increase in cellular proliferation, as evidenced by increased crypt length, crypt/villous ratio, mitotic index, PCNA labeling and decreased small bowel ulcer length. A possible explanation for such an observation is that intravenous nucleoside/ nucleotide administration could overcome the limitation of purine synthesis imposed by standard amino acids currently in clinical use, and promote cellular proliferation.

\section{Conclusion}

In conclusion, the management of the critically ill septic patient very often requires nutritional support therapy. Enteral feeding compared to parenteral feeding appears to reduce the risk of septic complications in the critically ill and high-risk surgical patients. In patients with an intact and functioning gastrointestinal tract, early enteral feeding (within $48 \mathrm{~h}$ ) should be the initial choice for supportive nutritional therapy. Evidence exists to support the benefits of enteral feeding in gut mucosa barrier function and immune status. However, the exact mechanism and contributing elements remain to be elucidated in detail.

\section{Acknowledgments}

This work has been in part supported by NATO Grant No. DK43796 and No. CA70239. 


\section{References}

1 Koretz RL: Nuritional supplementation in the ICU: How critical is nutrition for the critically ill? Am J Respir Crit Care Med 1995;151: 570-573.

2 Cerra FB: Hypermetabolism, organ failure, and metabolic support. Surgery $1987 ; 101: 1-14$.

3 Frost P, Bihari D: The route of nutritional support in the critically ill: Physiological and economical considerations. Nutrition 1997;13:58S$63 \mathrm{~S}$.

4 Adams S, Dellinger EP, Wertz MJ Oreskovich MR, Simonowitz D, Johansen K: Enteral versus parenteral nutritional support following laparotomy for trauma: A randomized prospective trial. J Trauma 1986;26: 882-891.

5 Wicks C, Somasundaram S, Bjarnason I, Menzies IS, Routley D, Potter D, Tan KC, Williams R: Comparison of enteral feeding and total parenteral nutrition after liver transplantation. Lancet 1994;344:837840.

6 Bower RH, Talamini MA, Sax HC, Hamilton F, Fischer JE: Postoperative enteral versus parenteral nutrition: A randomized controlled trial Arch Surg 1986;121:1040-1045

7 Illig KA, Ryan CK, Hardy DJ, Rhodes J, Locke W, Sax HC: Total parenteral nutrition-induced changes in gut mucosal function: Atrophy alone is not the issue. Surgery 1992; 112:631-637.

8 Seidner DL, Mascioli EA, Istfan NW, Porter KA, Selleck K, Blackburn GL, et al: Effects of long chain triglyceride emulsions on reticuloendothelial system function in humans. JPEN 1989;13:614-619.

9 Mughal MM: Complications of intravenous feeding catheters. $\mathrm{Br} \mathrm{J}$ Surg 1989;76:15-21.

10 Moore EE, Jones TN: Benefits of immediate jejunostomy feeding after major abdominal trauma: A prospective randomised study. J Trauma 1986;26:874-881.

11 Moore FA, Moore EE, Jones TN, McCroskey BL, Peterson VM: TEN versus TPN following major abdominal trauma: Reduced septic morbidity. J Trauma 1989;29:916-922.
12 Kudsk KA, Croce MA, Fabian TC, Minard G, Tolley EA, Poret HA Kuhl MR, Brown RO: Enteral versus parenteral feeding: Effects on septic morbidity after blunt and penetrating abdominal trauma. Ann Surg 1992;215:503-513.

13 Moore FA, Feliciano DV, Andrassy RJ, McArdle AH, Booth FV, Morgenstein-Wagner TB, Kellum JM Jr, Welling RE, Moore EE: Early enteral feeding, compared with parenteral reduces postoperative septic complications: The results of a metaanalysis. Ann Surg 1992;216:172182.

14 Alverdy JC, Aoys E, Moss GS: Total parenteral nutrition promotes bacterial translocation from the gut. Surgery 1988;104:185-190.

15 Deitch EA, Xu D, Naruhn MB, Deitch DC, Lu Q, Marino AA: Elemental diet and IV-TPN-induced bacterial translocation is associated with loss of intestinal mucosal barrier function against bacteria. Ann Surg 1995;221:299-307.

16 Levine GM, Deren JJ, Steiger E, Zinno R: Role of oral intake in maintenance of gut and disaccharide activity. Gastroenterology 1974;67:975-982.

17 Buchman AL, Moukarzel AA, Bhuta $\mathrm{S}$, Belle M, Ament ME, Eckhert CD, et al: Parenteral nutrition is associated with intestinal morphologic and functional changes in humans. JPEN 1995; 19:453-460.

18 Tremel H, Kienle B, Weilemann LS, Stehle P, Furst P: Glutamine dipeptide-supplemented parenteral nutrition maintains intestinal function in the critically ill. Gastroenterology 1994;107:1595-1601.

19 Burke DJ, Alverdy JC, Aoys E, Moos GS: Glutamine-supplemented total parenteral nutrition improves gut immune function. Arch Surg 1989;124:1396-1399.

20 Hwang TL, O'Dwyer ST, Smith RJ, Wilmore DW: Presentation of small bowel mucosa using glutamine-enriched parenteral nutrition. Surg Forum 1986;37:917.
21 Li M, Specian RD, Berg RD, Deitch EA: Effects of protein malnutrition and endotoxin on the intestinal mucosal barrier to the translocation of indigenous flora in mice. JPEN 1989;13:572-578.

22 Fong Y, Marano MA, Barber A, He W, Moldawer LL, Bushman ED, Coyle SM, Shires GT, Lowry SF: Total parenteral nutrition and bowel rest modify the metabolic response to endotoxin in humans. Ann Surg 1989;210:449-456.

23 Opera EI, Meguid MM, Yang ZJ, Chai JK, Veerabagu M: Tumor necrosis factor- $\alpha$ and total parenteral nutrition-induced anorexia. Surgery 1995;118:756-762.

24 Tracey KJ: TNF and other cytokines in the metabolism of septic shock and cachexia. Clin Nutr 1992;11:1.

25 Billiar TR, Curran RD: Kupffer cell and hepatocyte interactions: A brief overview. JPEN 1990;14:175S$180 \mathrm{~S}$.

26 Peterson VM, Moore EE, Jones TN, Rundus C, Emmett M, Moore FA, McCroskey BL, Haddix T, Parson PE: Total enteral nutrition vs. total parenteral nutrition after major torso injury: Attenuation of hepatic potein reprioritization. Surgery 1988 ; 104:199-207.

27 Suchner U, Senftleben U, Eckart T, Scholz MR, Beck K, Murr R, Enzebach R, Peter K: Enteral versus parenteral nutrition: Effects on gastrointestinal function and metabolism. Nutrition 1996;12:13-22.

28 Kudsk KA, Minard G, Wojtysiak SL, Croce M, Fabian T, Brown RO: Visceral protein response to enteral versus parenteral nutrition and sepsis in patients with trauma. Surgery 1994;116:516-523.

29 Cerra FB, Lehmann S, Konstantinides N, Dzik J, Fish J, Konstantinides F, LiCari JJ, Holman RT: Improvement of immune function in ICU patients by enteral nutrition supplemented with arginine, RNA, and menhaden oil is independent of nitrogen balance. Nutrition 1991;7: 193-199. 
30 Bower RH, Cerra FB, Bershadsky B, Licari JJ, Hoyt DB, Jensen GL, Van Buren CT, Rothkopf MM, Daly JM, Adelsberg BR: Early enteral administration of a formula (Impact) supplemented with arginine, nucleotides and fish oil in intensive care unit patients: Results of a multicenter, prospective, randomized, clinical trial. Crit Care Med 1995;23:436449.

31 Moore FA, Moore EE, Kudsk KA, Brown RO, Bower RH, Koruda MJ, Baker CC, Barbul A: Clinical benefits of an immune-enhancing diet for early postinjury enteral feeding. J Trauma 1994;37:607-615.

32 Kudsk KA, Minard G, Croce MA Brown RO, Lowrey TS, Pritchard FE, Dickerson RN, Fabian TC: A randomized trial of isonitrogenous enteral diets after severe trauma: An immune-enhancing diet reduces septic complications. Ann Surg 1996;224:531-540.
33 Ziegler TR, Young LS, Benfell K, Scheltinga M, Hortos K, Bye R, Morrow FD, Jacobs DO, Smith RJ, Antin JH, et al: Clinical and metabolic efficacy of glutamine-supplemented parenteral nutrition after bone marrow transplantation: A randomized, double-blind, controlled study. Ann Intern Med 1992; 116:821-828.

34 Schloerb PR, Amare M: Total parenteral nutrition with glutamine in bone marrow transplantation and other clinical application (a randomized, double-blind study). JPEN 1993;17:407-413.

35 Griffiths RD, Jones C, Palmer TE: Six-months outcome of critically ill patients given glutamine-supplemented parenteral nutrition. Nutrition 1997;13:295-302.

36 Klimberg VS, Souba WW, Dolson DJ, Salloum RM, Hautamaki RD Plumley DA, Mendenhall WM, Bova FJ, Khan SR, Hackett RL, et al: Prophylactic glutamine protects the intestinal mucosa from radiation injury. Cancer 1990;66:62-68.
37 Muscaritoli M, Micozzi A, Conversano L, Martino P, Petti MC, Cartoni C, Cascino A, Rossi Fanelli F: Oral glutamine in the prevention of chemotherapy-induced gastrointestinal toxicity. Eur J Cancer 1997;33: 319-320.

38 Spaeth G, Berg RD, Specian RD, Deitch EA: Food without fiber promotes bacterial translocation from the gut. Surgery 1990;108:240-246.

39 Wells CL, Barton RG, Jechorek RP Gillingham KJ, Cerra FB: Effect of fiber supplementation of liquid diet on cecal bacteria and bacterial translocation in mice. Nutrition 1992;8: 266-271.

40 Veerabagu MP, Meguid MM, Oler A, Levine RA: Intravenous nucleosides and a nucleotide promote healing of small bowel ulcers in experimental enterocolitis. Dig Dis Sci 1996;41:1452-1457. 